\title{
Erratum to: Continuously elevated serum matrix metalloproteinase-3 for 3 6 months predict one-year radiographic progression in rheumatoid arthritis: a prospective cohort study
}

Jian-Da Ma ${ }^{1}$, Xiu-Ning Wei ${ }^{1}$, Dong-Hui Zheng ${ }^{1}$, Ying-Qian $\mathrm{Mo}^{1}$, Le-Feng Chen ${ }^{1}$, Xiang Zhang ${ }^{2}$, Jin-Hua Li ${ }^{3}$ and Lie Dai ${ }^{1 *}$

Unfortunately, the original version of this article [1] contained an error. The author name 'Jing-Hua Li' was included incorrectly. This should be spelt 'Jin-Hua Li' as corrected in the author list above. The author name has been corrected in the original article also.

\section{Author details}

'Department of Rheumatology, Sun Yat-Sen Memorial Hospital, Sun Yat-Sen University, Guangzhou 510120, People's Republic of China. ${ }^{2}$ Department of Radiology, Sun Yat-Sen Memorial Hospital, Sun Yat-Sen University,

Guangzhou 510120, People's Republic of China. ${ }^{3}$ Department of Anatomy and Developmental Biology, Monash University, Clayton 3800 VIC, Australia.

Received: 27 October 2015 Accepted: 27 October 2015

Published online: 04 November 2015

\section{Reference}

1. Ma J-D, Wei X-N, Zheng D-H, Mo Y-Q, Chen L-F, Zhang X, Li J-H, Dai L. Continuously elevated serum matrix metalloproteinase-3 for $3 \sim 6$ months predict one-year radiographic progression in rheumatoid arthritis: a prospective cohort study. Arthritis Res Ther. 2015; 289.

\footnotetext{
* Correspondence: liedai2004@163.com

'Department of Rheumatology, Sun Yat-Sen Memorial Hospital, Sun Yat-Sen University, Guangzhou 510120, People's Republic of China
}

Submit your next manuscript to BioMed Central and take full advantage of:

- Convenient online submission

- Thorough peer review

- No space constraints or color figure charges

- Immediate publication on acceptance

- Inclusion in PubMed, CAS, Scopus and Google Scholar

- Research which is freely available for redistribution 